\author{
JURNAL EINSTEIN \\ Jurnal Hasil Penelitian Bindang Fisika \\ Available online http://jurnal.unimed.ac.id/2012/index.php/einsten \\ e-issn: $2407-747 x$, p-issn $2338-1981$
}

\title{
RANCANG BANGUN SISTEM PENGONTROL LAMPU OTOMATIS BERBASIS ARDUINO UNO R3 DAN SMARTPHONE
}

\author{
Zulkifli Girsang dan Winsyahputra Ritonga* \\ Jurusan Fisika, Fakultas Matematika dan Ilmu Pengetahuan Alam, Universitas Negeri Medan, \\ Indonesia \\ zulkifligirsang222@gmail.com \\ Diterima Februari 2018; Disetujui Februari 2018; Dipublikasikan Februari 2018
}

\begin{abstract}
ABSTRAK
Telah dilakukan penelitian rancang bangun sistem pengontol lampu otomatis menggunakan arduino uno $R 3$ berbasis smartphone dengan tujuan untuk menciptakan suatu alat yang dapat mengontrol hidup, mati dan intensitas lampu. Lampu merupakan suatu alat penerang yang digunakan didalam rumah, kantor dan sebagainya. Dengan adanya alat pengontrol lampu otomatis ini, maka pengguna dapat mengontrol hidup, mati serta intensitas dengan menggunakan smartphone, sehingga dapat mengurangi pemborosan pemakaian listrik. Dalam sistem pengontrol yang dirancang menggunakan mikrokontroler arduino uno R3, bluetooth HC-05, relay, Lcd 16x2, rangkaian diming, dilengkapi juga dengan led indikator relay. Sistem pengontrol dapat dikoneksikan ke smartphone karena telah dilengkapi dengan bluetooth $\mathrm{HC}$ 05 sebagai penerima data dari smartphone yang telah diinstal aplikasi pengontrol lampu otomatis. Dalam pengujian sistem pengontrol, bluetooth smartphone dapat terhubung dengan sistem pengontrol mencapai 30 meter tanpa penghalang dan 16 meter dengan penghalang. Pengujian pengontrolan di apikasikan dengan lampu 15 watt dan 3 watt dengan jarak pengujian dimulai 1 meter hingga 15 meter. Berdasarkan hasil pengujian dari sistem pengontrol dapat disimpulkan bahwa system dapat berjalan dan berfungsi dengan baik, setiap perintah dari smartphone dapat diproses mikrokontroler sehingga lampu dapat dikontrol. Aplikasi smartphone dirancang di App Inventor. Saklar pengontrolan terdiri dari penggontrolan menggunakan tombol on dan off, saklar suara, saklar timer dan saklar diming..
\end{abstract}

Kata Kunci : Lampu, Arduino Uno R3, rangkaian diming, Intensitas, App Inventor dan Bluetooth HC- 05

\section{PENDAHULUAN}

Perkembangan teknologi dan gaya hidup saat ini menunjukkan semakin pentingnya kepraktisan yang menyebabkan kebutuhan untuk mengontrol berbagai alat listrik tidak hanya dilakukan dengan mengharuskan seseorang berada di dekat piranti listrik. Dengan perkembangan teknologi saat ini, maka kebutuhan peralatan listrik atau elektronik di rumah, seperti menyalakan lampu rumah, menyalakan televisi atau radio, serta menyalakan berbagai peralatan rumah tangga, kegiatan itu semua lebih praktis jika bisa dikontrol dan dikendalikan dengan baik melalui aplikasi pengendali peralatan listrik (Isnawati, 2016 ).

Saat ini sudah banyak inovasi yang dilakukan dalam bidang teknologi, salah satunya 
adalah smarthome. Smarthome merupakan sistem yang diciptakan untuk mempermudah berbagai macam proses yang terjadi dalam rumah. Meliputi berbagai macam bidang, salah satu bidang yang telah ada adalah kontrol lampu rumah.

Smarthome Lighting Control System ini merupakan sebuah sistem yang bertujuan untuk memudahkan penggunanya dalam menyalakan dan memadamkan lampu rumah. Pekerjaan menyalakan dan memadamkan lampu rumah biasanya dilakukan secara manual, sehingga kita tidak dapat menghemat waktu dan tenaga dalam mengendalikan lampu lampu tersebut (Kholil, 2018).

Pada penelitian sebelumnya yang dilakukan Min Yan dan Hao Shi berhasil merancang dan membuat sebuah alat pengontrol lampu menggunakan bloetooth. Peneliti juga membuat sebuah aplikasi smartphone untuk mengontrol lampu dari smartphone. Pengontrol yang digunakan adalah sebuah microchip dan BF-10A. Pengontrol yang dibuat dapat bekerja sesuai tujuan dari pembuatan pengontrol.

Pada penelitian yang dilakukan henny dan sutardi, aplikasi yang dibangun masih sederhana yaitu hanya berfungsi untuk meng On dan Off kan lampu, sehingga untuk mengurangi kecerahan lampu belum bisa. Jarak pengontrolan juga masih sangat dekat hanya sebatas $9 \mathrm{~m}$ dengan penghalang dan $25 \mathrm{~m}$ tanpa penghalang.

Sehubungan dengan latar belakang tersebut maka penulis mengambil judul tentang "Rancang Bangun Sistem Pengontrol lampu Otomatis Berbasis Arduino Uno R3 dan Smartphone" .Dimana sistem pengontrol yang dirancang terdapat 4 buah pengontrolan yang terdapat dalam satu aplikasi. Pengontrolan menggunakan saklar On/Off, saklar suara, saklar diming dan saklar timer. Sehingga pengguna dapat memilih pengontrol yang sesuai dengan kebutuhan. Selain berfungsi untuk menghidupkan lampu, sistem juga dapat mengurangi kecerahan lampu. Sehingga tidak perlu mengganti bola lampu sesuai dengan kebutuhan. Sistem pengontrol juga bisa mengontrol waktu hidup lampu. Sehingga lampu dapat padam otomatis.

\section{METODE PENLITIAN}

Penelitian dilaksanakan di laboratorium Jurusan Fisika FMIPA Universitas Negeri Medan (UNIMED) selama 2 bulan.

Prosedur penelitian yang akan di lakukan dalam penelitian ini adalah sebagai berikut:

1. Membuat dan merancang perangkat keras sistem pengontrol lampu.

2. Membuat miniatur rumah

3. Menggbungkan miniatur dan perangkat keras.

4. Merancang aplikasi smartphone pengontrol lampu otomatis dalam app inventor.

5. Mengupload program kedalam perangkat keras sistem pengontrol lampu.

Diagram blok rangkaian merupakan salah satu bagian terpenting dalam perancangan alat, karena dari diagram blok tersebut dapat diketahui cara kerja (prinsip kerja) keseluruhan rangkaian. Sehingga keseluruhan diagram blok rangkaian tersebut akan menghasilkan suatu sistem yang dapat difungsikan atau sistem yang bekerja sesuai dengan perancangan. Keseluruhan diagram blok rangkaian dapat dilihat dalam gambar 3.1.

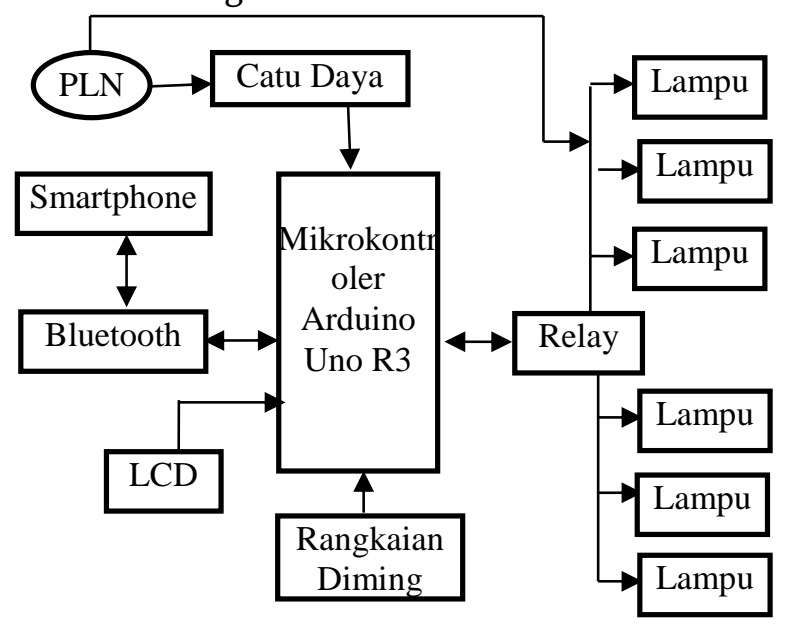

Gambar 3.1. Diagram blok sistem

Pada penelitian ini, langkah-langkah yang akan dilakukan dalam menganalisa data, yaitu:

1. Analisis data yang akan disajikan dalam bentuk tabel yaitu hasil pengumpulan data dengan variasi jarak pengontrolan dan variasi kecerahan lampu. 
2. Metode yang digunakan dalam menganalisis hasil dari penelitian ini adalah metode eksperimen, yaitu dengan menguji kemampuan bluetooth mengontrol hidup dan mati lampu dan mengatur kecerahan lampu dengan menggunakan smartphone sebagai saklar dan rangkaian diming sebagai pengubah kecerahan lampu.

\section{HASIL DAN PEMBAHASAN \\ Hasil Penelitian}

Dalam perancangan penelitian ini terdapat dua bagian, yaitu perangkat keras (hardware) danperangkat lunak (software). Perangkatkeras yang digunakan terdiri dari, modul Arduino Uno R3 dengan mikrokontroler ATMega328, relay, Bluetooth, relay, lampu, led indikator,kipas, rangkaian diming dan LCD (Liquid Crystal Display) ukuran 16x2. Perangkat lunak (software) yang digunakan yaitu bahasa processing danwriting platform atau yang lebih dikenal dengan bahasa C, Corel Draw X5 dan Aplikasi Smartphone yang dirancang.

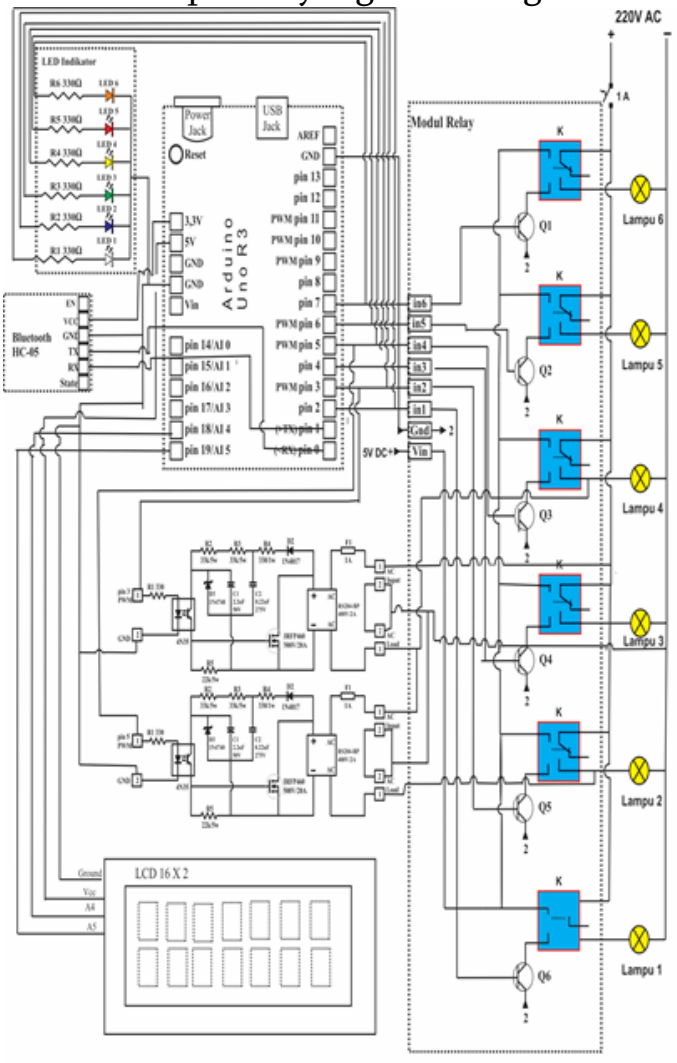

Gambar 4.1. Skema rangkaian sistem
Pada gambar skema rangkaian diatas, dapat dituangkan dalam bentuk nyata yang dapat dilihat pada gambar 4.2.

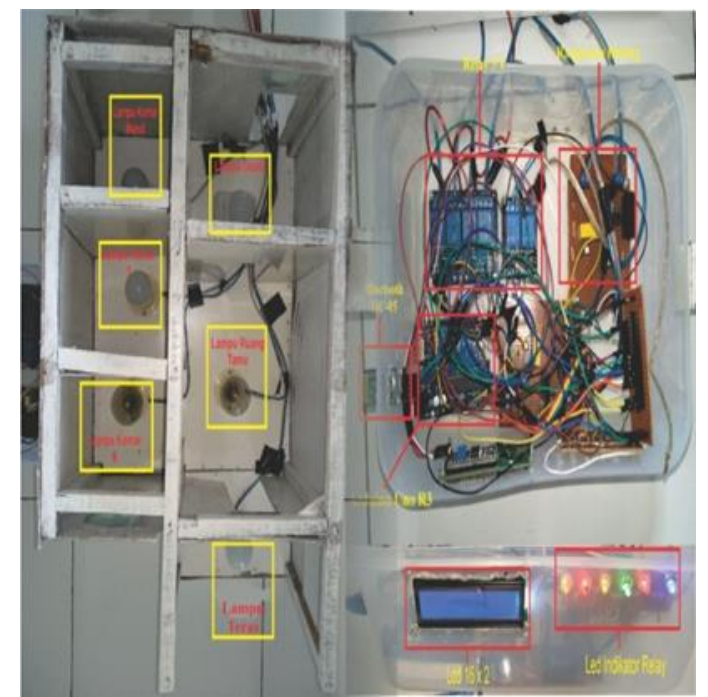

Gambar 4.2. Bentuk fisik dari sistem pengontrol yang telah dirancang

Pengontrolan lampu dapat dilakukan setelah aplikasi smartphone yang dirancang dapat tersambung dengan sistem pengontrol yang telah dirancang. Aplikasi smartphone hasil rancangan dapat dilihat pada gambar 4.3.

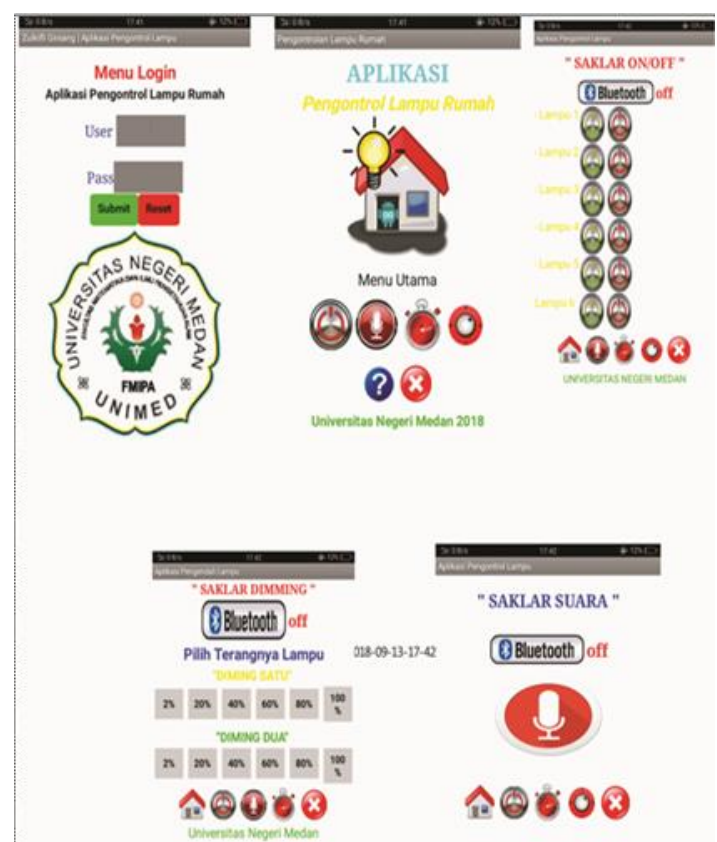

Gambar 4.3. Aplikasi smartphone pengontrol lampu

Berikut data pengujian jarak koneksi bluetooth dengan smartphone tanpa penghalang dan dengan penghalang pada tabel 4.1. 
Tabel 4.1. Hasil pengujian koneksi bluetooth dengan smartphone tanpa penghalang

\begin{tabular}{|c|c|c|l|}
\hline No & Jarak & Status Koneksi & Waktu Koneksi \\
\hline 1 & 1 meter & Terhubung & 1 detik \\
\hline 2 & 2 meter & Terhubung & 1,5 detik \\
\hline 3 & 3 meter & Terhubung & 2 detik \\
\hline 4 & 4 meter & Terhubung & 2 detik \\
\hline 5 & 5 meter & Terhubung & 2,5 detik \\
\hline 6 & 6 meter & Terhubung & 3 detik \\
\hline 7 & 7 meter & Terhubung & 3,2 detik \\
\hline 8 & 8 meter & Terhubung & 3,2 detik \\
\hline 9 & 9 meter & Terhubung & 3,2 detik \\
\hline 10 & 10 meter & Terhubung & 3,4 detik \\
\hline 11 & 11 meter & Terhubung & 3,5 detik \\
\hline 12 & 12 meter & Terhubung & 3,8 detik \\
\hline 13 & 13 meter & Terhubung & 4 detik \\
\hline 14 & 14 meter & Terhubung & 4 detik \\
\hline 15 & 15 meter & Terhubung & 4 detik \\
\hline 16 & 16 meter & Terhubung & 4 detik \\
\hline 17 & 17 meter & Terhubung & 4,2 detik \\
\hline 18 & 18 meter & Terhubung & 4,4 detik \\
\hline 19 & 19 meter & Terhubung & 4,4 detik \\
\hline 20 & 20 meter & Terhubung & 4,4 detik \\
\hline 21 & 21 meter & Terhubung & 5 detik \\
\hline 22 & 22 meter & Terhubung & 5,2 detik \\
\hline 23 & 23 meter & Terhubung & 5,4 detik \\
\hline 24 & 24 meter & Terhubung & 5,6 detik \\
\hline 25 & 25 meter & Terhubung & 6 detik \\
\hline 26 & 26 meter & Terhubung & 6 detik \\
\hline 27 & 27 meter & Terhubung & 6,3 detik \\
\hline 28 & 28 meter & Terhubung & 6,8 detik \\
\hline 29 & 29 meter & Terhubung & 7 detik \\
\hline 30 & 30 meter & Terhubung & 7,4 detik \\
\hline
\end{tabular}

Tabel 4.2. Hasil pengujian koneksi bluetooth dengan smartphone dengan penghalang

\begin{tabular}{|l|l|l|l|}
\hline No & Jarak & Status Koneksi & Waktu Koneksi \\
\hline 1 & 1 meter & Terhubung & 1 detik \\
\hline 2 & 2 meter & Terhubung & 1,5 detik \\
\hline 3 & 3 meter & Terhubung & 2 detik \\
\hline 4 & 4 meter & Terhubung & 2 detik \\
\hline 5 & 5 meter & Terhubung & 3,5 detik \\
\hline 6 & 6 meter & Terhubung & 3,5 detik \\
\hline 7 & 7 meter & Terhubung & 3,7 detik \\
\hline 8 & 8 meter & Terhubung & 3,7 detik \\
\hline 9 & 9 meter & Terhubung & 3,8 detik \\
\hline 10 & 10 meter & Terhubung & 3,8 detik \\
\hline 11 & 11 meter & Terhubung & 3,8 detik \\
\hline 12 & 12 meter & Terhubung & 4 detik \\
\hline 13 & 13 meter & Terhubung & 4 detik \\
\hline 14 & 14 meter & Terhubung & 4 detik \\
\hline 15 & 15 meter & Terhubung & 4,5 detik \\
\hline 16 & 16 meter & Terhubung &
\end{tabular}

Berdasarkan tabel hasil data percobaan bluetooth akan menstranmisikan data yang akan dikirim dengan menggunakan frekuensi dari bluetooth smartphone ke modul bluetooth yang berada pada rangkaian Arduino Uno R3.

Pengujian sistem pengontrol lampu dilakukan dengan cara menguji setiap saklar yang sudah ada dalam aplikasi smartphone terdiri dari 4 saklar yaitu :

1. Pengontrolan menggunakan saklar tombol on/off

2. Pengontrolan menggunakan saklar suara.

3. Pengontrolan menggunakan saklar timer.

4. Pengontrolan menggunakan saklar diming

Tabel 4.3. Pengujian saklar tombol on/off

\begin{tabular}{|c|c|c|c|c|c|}
\hline No & $\begin{array}{l}\text { Nama } \\
\text { Lampu }\end{array}$ & $\begin{array}{l}\text { Jarak } \\
(\mathrm{m})\end{array}$ & $\begin{array}{l}\text { On/ } \\
\text { off }\end{array}$ & $\begin{array}{l}\text { Waktu } \\
\text { Respon } \\
\text { (s) }\end{array}$ & Kesimpulan \\
\hline \multirow[t]{8}{*}{1} & \multirow{8}{*}{$\begin{array}{l}\text { Lampu } \\
1\end{array}$} & 1 & On & 1 & Sistem Berfungsi \\
\hline & & 3 & Off & 1 & Sistem Berfungsi \\
\hline & & 5 & On & 1 & Sistem Berfungsi \\
\hline & & 7 & Off & 1 & Sistem Berfungsi \\
\hline & & 9 & On & 1,2 & Sistem Berfungsi \\
\hline & & 11 & Off & 1,5 & Sistem Berfungsi \\
\hline & & 13 & On & 1,6 & Sistem Berfungsi \\
\hline & & 15 & Off & 2 & Sistem Berfungsi \\
\hline \multirow[t]{8}{*}{2} & \multirow{8}{*}{$\begin{array}{l}\text { Lampu } \\
2\end{array}$} & 1 & On & 1 & Sistem Berfungsi \\
\hline & & 3 & Off & 1 & Sistem Berfungsi \\
\hline & & 5 & On & 1 & Sistem Berfungsi \\
\hline & & 7 & Off & 1 & Sistem Berfungsi \\
\hline & & 9 & On & 1,2 & Sistem Berfungsi \\
\hline & & 11 & Off & 1,2 & Sistem Berfungsi \\
\hline & & 13 & On & 1,6 & Sistem Berfungsi \\
\hline & & 15 & Off & 2 & Sistem Berfungsi \\
\hline \multirow[t]{8}{*}{3} & \multirow{8}{*}{$\begin{array}{l}\text { Lampu } \\
3\end{array}$} & 1 & On & 1 & Sistem Berfungsi \\
\hline & & 3 & Off & 1 & Sistem Berfungsi \\
\hline & & 5 & On & 1 & Sistem Berfungsi \\
\hline & & 7 & Off & 1,2 & Sistem Berfungsi \\
\hline & & 9 & On & 1,3 & Sistem Berfungsi \\
\hline & & 11 & Off & 1,5 & Sistem Berfungsi \\
\hline & & 13 & On & 1,8 & Sistem Berfungsi \\
\hline & & 15 & Off & 2 & Sistem Berfungsi \\
\hline \multirow[t]{8}{*}{4} & \multirow{8}{*}{$\begin{array}{l}\text { Lampu } \\
4\end{array}$} & 1 & On & 1 & Sistem Berfungsi \\
\hline & & 3 & Off & 1 & Sistem Berfungsi \\
\hline & & 5 & On & 1 & Sistem Berfungsi \\
\hline & & 7 & Off & 1,2 & Sistem Berfungsi \\
\hline & & 9 & On & 1,2 & Sistem Berfungsi \\
\hline & & 11 & Off & 1,4 & Sistem Berfungsi \\
\hline & & 13 & On & 1,5 & Sistem Berfungsi \\
\hline & & 15 & Off & 1,8 & Sistem Berfungsi \\
\hline \multirow[t]{8}{*}{5} & \multirow{8}{*}{$\begin{array}{l}\text { Lampu } \\
5\end{array}$} & 1 & Off & 1 & Sistem Berfungsi \\
\hline & & 3 & On & 1 & Sistem Berfungsi \\
\hline & & 5 & Off & 1 & Sistem Berfungsi \\
\hline & & 7 & Off & 1 & Sistem Berfungsi \\
\hline & & 9 & On & 1 & Sistem Berfungsi \\
\hline & & 11 & Off & 1,2 & Sistem Berfungsi \\
\hline & & 13 & On & 1,2 & Sistem Berfungsi \\
\hline & & 15 & Off & 1,8 & Sistem Berfungsi \\
\hline \multirow[t]{8}{*}{6} & \multirow{8}{*}{$\begin{array}{l}\text { Lampu } \\
6\end{array}$} & 1 & Off & 1 & Sistem Berfungsi \\
\hline & & 3 & On & 1 & Sistem Berfungsi \\
\hline & & 5 & Off & 1 & Sistem Berfungsi \\
\hline & & 7 & Off & 1 & Sistem Berfungsi \\
\hline & & 9 & On & 1,4 & Sistem Berfungsi \\
\hline & & 11 & Off & 1,4 & Sistem Berfungsi \\
\hline & & 13 & On & 1,8 & Sistem Berfungsi \\
\hline & & 15 & Off & 2 & Sistem Berfungsi \\
\hline
\end{tabular}


Pengontrolan menggunakan saklar on/off dapat bekerja dengan baik sampai dengan jarak hingga 15 meter. Sesuai dengan data yang didapat setelah pengujian, waktu responnya juga cukup cepat yaitu maksimal 2,5 sekon.

Tabel 4.4. Pengujian saklar Suara

\begin{tabular}{|c|c|c|c|c|}
\hline No & Perintah & $\begin{array}{l}\text { Jarak } \\
\text { (m) }\end{array}$ & $\begin{array}{l}\text { Waktu } \\
\text { Respon } \\
\text { (s) }\end{array}$ & Kesimpulan \\
\hline \multirow[t]{8}{*}{1} & \multirow{8}{*}{$\begin{array}{l}\text { Hidupkan } \\
\text { Lampu } \\
\text { Teras }\end{array}$} & 1 & 1,2 & Sistem Berfungsi \\
\hline & & 3 & 1,2 & Sistem Berfungsi \\
\hline & & 5 & 1,2 & Sistem Berfungsi \\
\hline & & 7 & 1,5 & Sistem Berfungsi \\
\hline & & 9 & 1,7 & Sistem Berfungsi \\
\hline & & 11 & 1,9 & Sistem Berfungsi \\
\hline & & 13 & 2,1 & Sistem Berfungsi \\
\hline & & 15 & 2,2 & Sistem Berfungsi \\
\hline \multirow[t]{8}{*}{2} & \multirow{8}{*}{$\begin{array}{l}\text { Matikan } \\
\text { Lampu } \\
\text { Teras }\end{array}$} & 1 & 1,2 & Sistem Berfungsi \\
\hline & & 3 & 1,2 & Sistem Berfungsi \\
\hline & & 5 & 1,2 & Sistem Berfungsi \\
\hline & & 7 & 1,5 & Sistem Berfungsi \\
\hline & & 9 & 1,7 & Sistem Berfungsi \\
\hline & & 11 & 1,9 & Sistem Berfungsi \\
\hline & & 13 & 2,1 & Sistem Berfungsi \\
\hline & & 15 & 2,2 & Sistem Berfungsi \\
\hline \multirow[t]{8}{*}{3} & \multirow{8}{*}{$\begin{array}{l}\text { Hidupkan } \\
\text { lampu ruang } \\
\text { tamu }\end{array}$} & 1 & 1,2 & Sistem Berfungsi \\
\hline & & 3 & 1,2 & Sistem Berfungsi \\
\hline & & 5 & 1,3 & Sistem Berfungsi \\
\hline & & 7 & 1,5 & Sistem Berfungsi \\
\hline & & 9 & 1,6 & Sistem Berfungsi \\
\hline & & 11 & 1,8 & Sistem Berfungsi \\
\hline & & 13 & 2 & Sistem Berfungsi \\
\hline & & 15 & 2,2 & Sistem Berfungsi \\
\hline \multirow[t]{8}{*}{4} & \multirow{8}{*}{$\begin{array}{l}\text { Matikan } \\
\text { Lampu } \\
\text { Ruang Tamu }\end{array}$} & 1 & 1 & Sistem Berfungsi \\
\hline & & 3 & 1 & Sistem Berfungsi \\
\hline & & 5 & 1 & Sistem Berfungsi \\
\hline & & 7 & 1,2 & Sistem Berfungsi \\
\hline & & 9 & 1,2 & Sistem Berfungsi \\
\hline & & 11 & 1,4 & Sistem Berfungsi \\
\hline & & 13 & 1,5 & Sistem Berfungsi \\
\hline & & 15 & 1,8 & Sistem Berfungsi \\
\hline \multirow[t]{8}{*}{5} & \multirow{8}{*}{$\begin{array}{l}\text { Hidupkan } \\
\text { Lampu } \\
\text { Kamar } 1\end{array}$} & 1 & 1,2 & Sistem Berfungsi \\
\hline & & 3 & 1,2 & Sistem Berfungsi \\
\hline & & 5 & 1,4 & Sistem Berfungsi \\
\hline & & 7 & 1,5 & Sistem Berfungsi \\
\hline & & 9 & 1,3 & Sistem Berfungsi \\
\hline & & 11 & 1,6 & Sistem Berfungsi \\
\hline & & 13 & 1,8 & Sistem Berfungsi \\
\hline & & 15 & 2,1 & Sistem Berfungsi \\
\hline \multirow[t]{8}{*}{6} & \multirow{8}{*}{$\begin{array}{l}\text { Matikan } \\
\text { Lampu } \\
\text { Kamar } 1\end{array}$} & 1 & 1 & Sistem Berfungsi \\
\hline & & 3 & 1,2 & Sistem Berfungsi \\
\hline & & 5 & 1,4 & Sistem Berfungsi \\
\hline & & 7 & 1,3 & Sistem Berfungsi \\
\hline & & 9 & 1,6 & Sistem Berfungsi \\
\hline & & 11 & 1,7 & Sistem Berfungsi \\
\hline & & 13 & 1,6 & Sistem Berfungsi \\
\hline & & 15 & 1,8 & Sistem Berfungsi \\
\hline \multirow[t]{8}{*}{7} & \multirow{8}{*}{$\begin{array}{l}\text { Hidupkan } \\
\text { Lampu } \\
\text { kamar } 2\end{array}$} & 1 & 1 & Sistem Berfungsi \\
\hline & & 3 & 1 & Sistem Berfungsi \\
\hline & & 5 & 1,2 & Sistem Berfungsi \\
\hline & & 7 & 1,2 & Sistem Berfungsi \\
\hline & & 9 & 1,4 & Sistem Berfungsi \\
\hline & & 11 & 1,5 & Sistem Berfungsi \\
\hline & & 13 & 1,8 & Sistem Berfungsi \\
\hline & & 15 & 2,2 & Sistem Berfungsi \\
\hline \multirow[t]{6}{*}{8} & & 1 & 1 & Sistem Berfungsi \\
\hline & Lampu & 3 & 1,2 & Sistem Berfungsi \\
\hline & & 5 & 1,1 & Sistem Berfungsi \\
\hline & & 7 & 1,3 & Sistem Berfungsi \\
\hline & & 9 & 1,5 & Sistem Berfungsi \\
\hline & & 11 & 1,5 & Sistem Berfungsi \\
\hline
\end{tabular}

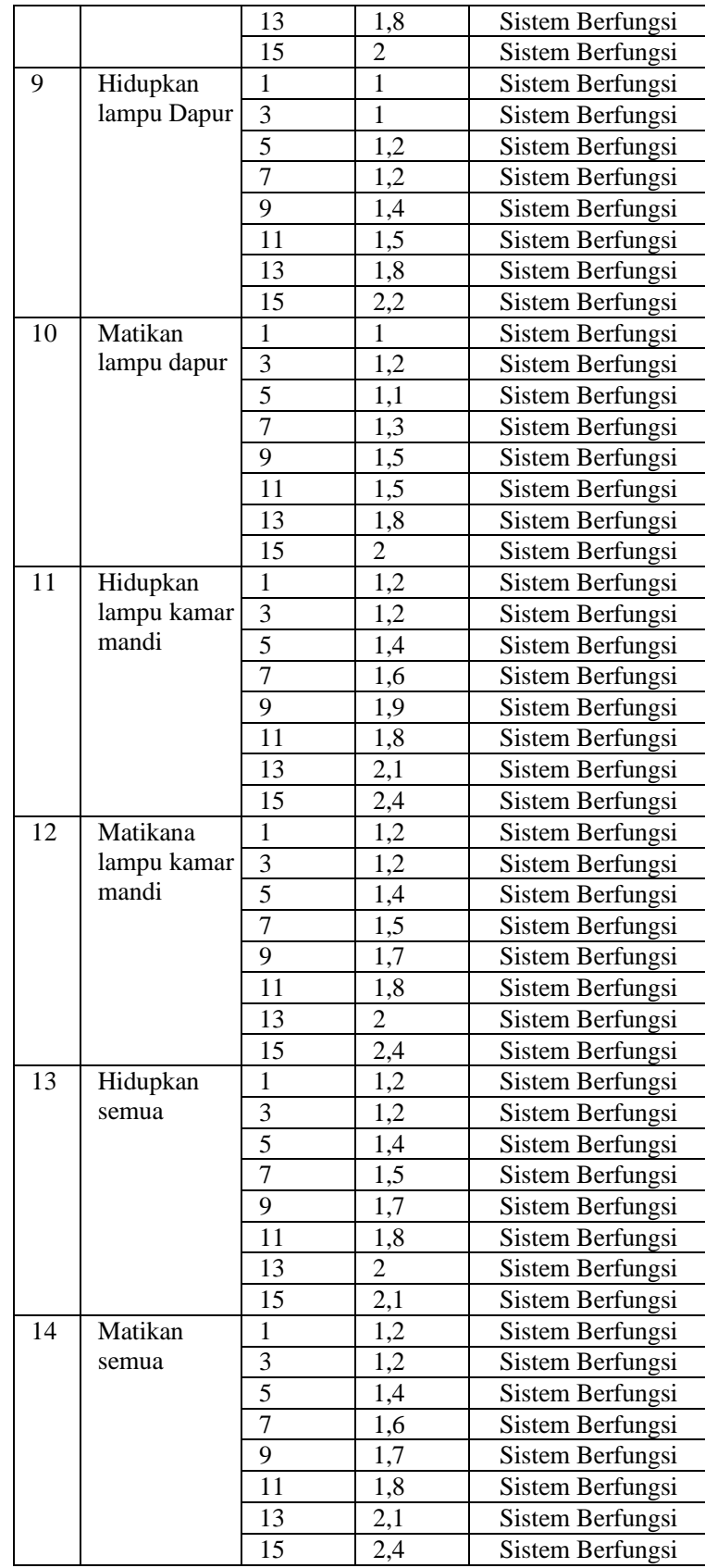

Sistem pengontrolan menggunakan saklar suara dalam pengontrolan lampu berfungsi dengan baik. Waktu respon sistem pengontrol cukup cepat. Pengontrolan menggunakan saklar suara ini memerlukan akses internet. Dimana untuk pembacaan suara aplikasi menggunakan google spech. Google spech ini berfungsi untuk pembacaan suara yang di ucapkan.

Tabel 4.5. Pengujian saklar Timing

\begin{tabular}{|l|l|l|l|}
\hline No & $\begin{array}{l}\text { Waktu } \\
\text { Hidup }\end{array}$ & Status Lampu & Kesimpulan \\
\hline $\mathbf{1}$ & 11 jam & $\begin{array}{l}\text { Lampu Hidup selama 11 } \\
\text { jam setelah itu mati }\end{array}$ & Sistem Berfungsi \\
$\mathbf{2}$ & 12 jam & $\begin{array}{l}\text { Lampu hidup selama 12 } \\
\text { jam setelah itu mati } \\
\text { Lampu hidup selama 13 } \\
\text { jam setelah itu mati }\end{array}$ & Sistem Berfungsi \\
$\mathbf{3}$ & 13 jam & Sistem Berfungsi \\
\hline
\end{tabular}


Sistem kerja dari saklar timing bekerja dengan cara memberikan timer untuk semua lampu yang tersambung dengan sistem pengontrol yang dibuat.Untuk saklar yang dibuat ada tiga variasi yaitu untuk 11 jam, 12 jam dan 13 jam. Lampu akan otomatis mati ketika waktu hidup lampu yang sudah di tentukan melalui saklar timing berakhir (habis).

Tabel 4.6. Pengujian saklar Timing

\begin{tabular}{|c|c|c|c|c|}
\hline No & $\begin{array}{l}\text { Kecerahan } \\
\text { lampu }\end{array}$ & $\begin{array}{l}\text { Jarak } \\
(\mathrm{m})\end{array}$ & $\begin{array}{l}\text { Waktu } \\
\text { Respon } \\
\text { (s) }\end{array}$ & Kesimpulan \\
\hline \multirow[t]{8}{*}{1} & \multirow[t]{8}{*}{$2 \%$} & 1 & 1 & Sistem Berfungsi \\
\hline & & 3 & 1 & Sistem Berfungsi \\
\hline & & 5 & 1,2 & Sistem Berfungsi \\
\hline & & 7 & 1,2 & Sistem Berfungsi \\
\hline & & 9 & 1,3 & Sistem Berfungsi \\
\hline & & 11 & 1,5 & Sistem Berfungsi \\
\hline & & 13 & 1,6 & Sistem Berfungsi \\
\hline & & 15 & 1,9 & Sistem Berfungsi \\
\hline \multirow[t]{8}{*}{2} & \multirow[t]{8}{*}{$20 \%$} & 1 & 1,2 & Sistem Berfungsi \\
\hline & & 3 & 1,5 & Sistem Berfungsi \\
\hline & & 5 & 1,4 & Sistem Berfungsi \\
\hline & & 7 & 1,8 & Sistem Berfungsi \\
\hline & & 9 & 1,5 & Sistem Berfungsi \\
\hline & & 11 & 1,7 & Sistem Berfungsi \\
\hline & & 13 & 1,9 & Sistem Berfungsi \\
\hline & & 15 & 2,3 & Sistem Berfungsi \\
\hline \multirow[t]{8}{*}{3} & \multirow[t]{8}{*}{$40 \%$} & 1 & 1 & Sistem Berfungsi \\
\hline & & 3 & 1,3 & Sistem Berfungsi \\
\hline & & 5 & 1,4 & Sistem Berfungsi \\
\hline & & 7 & 1,2 & Sistem Berfungsi \\
\hline & & 9 & 1,6 & Sistem Berfungsi \\
\hline & & 11 & 1,8 & Sistem Berfungsi \\
\hline & & 13 & 2 & Sistem Berfungsi \\
\hline & & 15 & 2,1 & Sistem Berfungsi \\
\hline \multirow[t]{8}{*}{4} & \multirow[t]{8}{*}{$60 \%$} & 1 & 1,2 & Sistem Berfungsi \\
\hline & & 3 & 1,2 & Sistem Berfungsi \\
\hline & & 5 & 1,4 & Sistem Berfungsi \\
\hline & & 7 & 1,6 & Sistem Berfungsi \\
\hline & & 9 & 1,7 & Sistem Berfungsi \\
\hline & & 11 & 1,9 & Sistem Berfungsi \\
\hline & & 13 & 2,2 & Sistem Berfungsi \\
\hline & & 15 & 2,4 & Sistem Berfungsi \\
\hline \multirow[t]{8}{*}{5} & \multirow[t]{8}{*}{$80 \%$} & 1 & 1,2 & Sistem Berfungsi \\
\hline & & 3 & 1,3 & Sistem Berfungsi \\
\hline & & 5 & 1,4 & Sistem Berfungsi \\
\hline & & 7 & 1,6 & Sistem Berfungsi \\
\hline & & 9 & 1,8 & Sistem Berfungsi \\
\hline & & 11 & 1,9 & Sistem Berfungsi \\
\hline & & 13 & 2.1 & Sistem Berfungsi \\
\hline & & 15 & 2,3 & Sistem Berfungsi \\
\hline \multirow[t]{8}{*}{6} & \multirow[t]{8}{*}{$100 \%$} & 1 & 1,1 & Sistem Berfungsi \\
\hline & & 3 & 1,3 & Sistem Berfungsi \\
\hline & & 5 & 1,5 & Sistem Berfungsi \\
\hline & & 7 & 1,6 & Sistem Berfungsi \\
\hline & & 9 & 1,7 & Sistem Berfungsi \\
\hline & & 11 & 1,8 & Sistem Berfungsi \\
\hline & & 13 & 2,1 & Sistem Berfungsi \\
\hline & & 15 & 2,3 & Sistem Berfungsi \\
\hline
\end{tabular}

Pengontrolan menggunakan saklar diming bekerja dengan baik dan setiap pengujian berfungsi dengan baik. Dengan adanya sistem pengontrol diming ini sangat membantu dalam mengurangi penggunaan listrik. Rangkaian diming ini hanya dapat menggunakan lampu mempunyai daya maksimal 100 Watt. Untuk pengujian mencapai 15 meter dan seluruh perintah dapat diterima dan diproses sistem pengontrol.

Tabel 4.7. Pengukuran Nilai Daya Dan Intensitas Cahaya Lampu

\begin{tabular}{|l|l|l|l|l|l|l|l|}
\hline No & $\begin{array}{l}\text { Kecerahan } \\
\text { Lampu }\end{array}$ & $\begin{array}{l}\text { Tegangan } \\
\text { (V) }\end{array}$ & $\begin{array}{l}\text { Arus } \\
(\mathrm{A})\end{array}$ & $\begin{array}{l}\text { Daya } \\
\text { (Watt) }\end{array}$ & $\begin{array}{l}\text { Intensita } \\
\text { jjarak } \\
10 \mathrm{~cm} \\
\text { (Lumen) }\end{array}$ & $\begin{array}{l}\text { Intensitas } \\
\text { jarak } \\
30 \mathrm{~cm} \\
(\text { Lumen })\end{array}$ & $\begin{array}{l}\text { Intensitas } \\
\text { jarak } \\
50 \mathrm{~cm} \\
(\text { Lumen) }\end{array}$ \\
\hline 1 & $2 \%$ & 78 & 0,069 & 5,382 & 492 & 320 & 186 \\
\hline 2 & $20 \%$ & 182 & 0,069 & 12,558 & 1267 & 707 & 568 \\
\hline 3 & $40 \%$ & 189 & 0,069 & 13,041 & 1791 & 748 & 621 \\
\hline 4 & $60 \%$ & 195 & 0,069 & 13,445 & 2190 & 1100 & 696 \\
\hline 5 & $80 \%$ & 199 & 0,069 & 13,731 & 2750 & 1240 & 731 \\
\hline 6 & $100 \%$ & 204 & 0,069 & 14,076 & 3160 & 1465 & 784 \\
\hline
\end{tabular}

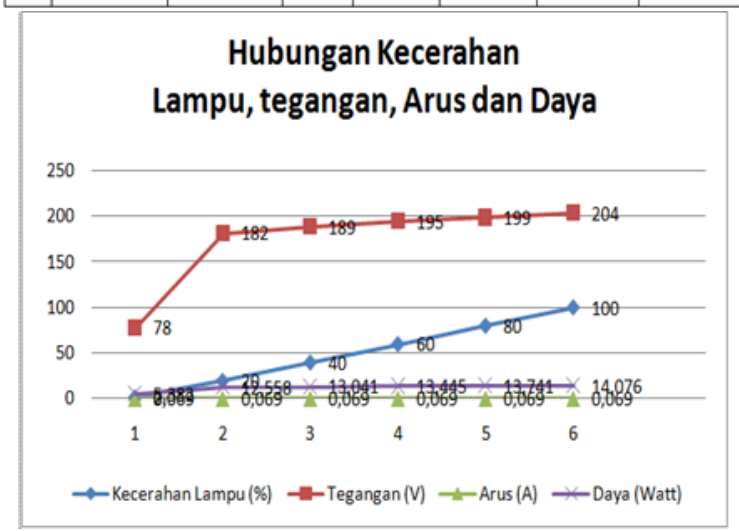

Gambar 4.4. Kurva hubungan intensitas lampu, tegangan, arus dan daya

Dari tabel dan kurva dapat diketahui bahwa setiap perubahan kecerahan cahaya lampu maka nilai tegangan juga akan semakin besar. Daya juga berbanding lurus dengan nilai lumen yang dihasilkan oleh lampu, dimana semakin besar nilai daya pada lampu maka nilai lumen juga semakin besar.

\section{Pembahasan}

Berdasarkan data hasil penelitian, didapat bahwa rancangan alat sistem pengontrol lampu otomatis menggunakan mikrokontroler Arduino Uno R3 dengan memanfaatkan bluetooth dan smartphone dapat berjalan dan berfungsi dengan baik. Hal ini dapat dilihat dari kemampuan alat untuk mengontrol lampu untuk on dan off serta mengatur kecerahan dengan tampilan $L C D$ sebagai indikator perintah di sistem pengontrol dan tampilan smartphone sebagai tampilan untuk pengontrol. Sistem pengontrol juga dilengkapi $L E D$ sebagai indikator untuk setiap lampu. Apabila indikator $L E D$ tersebut off 
maka lampu akan off. Untuk aplikasi Smartphone di rancang di App Inventor. Supaya dapat bekerja di Web App Inventor membutuhkan koneksi dengan internet (perancangan dilakukan secara online). Cara menginstal aplikasi smartphone yang telah dirancang yaitu dengan menyimpan dalam bentuk file $A p k$ di komputer dan memindahkannya ke smartphone. Kemudian membuka file dan menekan tombol instal. Maka aplikasi smartphone akan terinstal di smartphone yang akan digunakan untuk pengontrol lampu.

Kemampuan koneksi antara bluetooth sistem pengontrol dengan bloetooth smartphone dapat terhubung dengan jarak 30 meter tanpa penghalang dan dengan penghalang sampai 16 meter. Waktu yang dibutuhkan untuk menghubungkan kedua bluetooth memiliki waktu yang berbeda. Semakin jauh jarak antara bluetooth maka waktu yang diperlukan semakin lama. Hal ini disebabkan oleh salah satu sifat gelombang elektromagnetik yaitu bersifat memantulkan. Bluetooth merupakan salah satu perangkat elektronik yang memanfaatkan gelombang elektromagnetik. Karena gelombang elektromagnetik bersifat memantulkan sehingga semakin jauh jarak antara bluetooth sistem pengotrol dengan bluetooth smartphone maka pemantulan gelombang akan lebih sering terjadi sehingga waktu yang diperlukan untuk menghubungkan kedua perangkat bluetooth semakin lama. Dimana untuk pengujian tanpa penghalang (di lapangan terbuka) jarak 1 meter dibutuhkan waktu 1 detik dan untuk 30 meter dibutuhkan waktu 7,4 detik. Untuk pengujian dengan penghalang (seperti di rumah) untuk 1 meter dibutuhkan waktu 1 detik dan untuk 16 meter 4,5 detik tetapi untuk jarak 17 meter tidak terkoneksi lagi (terputus).

\section{KESIMPULAN DAN SARAN}

Setelah dilakukan pembuatan alat sistem pengontrol lampu menggunakan arduino uno r3 berbasis smartphone kemudian melakukan pengujian alat, maka dapat diambil kesimpulan :

1. Sistem pengontrol lampu otomatis dirancang menggunakan beberapa alat dan bahan yaitu Arduino Uno R3 sebagai mikrokontroler, bluetooth HC 05 sebagai alat komunikasi antara smartphone dengan sistem pengontrol, relay sebagai saklar lampu, rangkaian diming sebagai pengontrol kecerahan lampu, LCD, smartphone, laptop, kabel jumper, kabel dan miniatur rumah beserta lampu sebanyak 6 buah. Sistem pengontrol lampu otomatis dibuat dengan merangkai seluruh komponen alat dengan kabel jumper sebagai penghubung antar komponen. Setelah rangkaian selesai dirancang, kemudian membuat miniatur rumah yang sudah dilengkapi dengan lampu. Kemudian penggabungan rangkaian dengan miniatur. Setelah penggabungan selesai dilakukan, program diupload menggunakan laptop yang sudah di lengkapi dengan software Arduino Uno.

2. Aplikasi smartphone dirancang menggunakan aplikasi app inventor yang disediakan oleh google. Untuk dapat login pengguna harus menggunakan $E$ mail yang terdaftar di google. Setelah dapat login dan halaman kerja app inventor tebuka maka app inventor siap digunakan. Untuk pembuatan istem pengontrol lampu otomatis, sistem menggunakan 4 saklar pengontrolan yaitu pengontrolan menggunakan saklar on/off, saklar suara, saklar timer dan saklar diming. Dalam perancangan aplikasi smartphone, perintah yang di input dalam app inventor harus sesuai dengan program yang diupload dirangkaian sistem pengontrol. Apabila perintah yang diupload dalam rangkaian tidak sesuai dengan perintah yang diinput di aplikasi smartphone, maka aplikasi smartphone yang dirancang tidak berfungsi.

Berdasarkan hasil penelitian sistem pengontrol lampu otomatis ini, peneliti memberikan saran untuk penelitian selanjutnya, yaitu :

1. Untuk mengatasi terbatasnya jarak, penulis menyarankan untuk pengontrolan menggunakan bluetooth yang lebih jauh jangkauannya atau 
dengan memanfaatkan jaringan internet sehingga tidak terbatas oleh jarak

2. Untuk mengatasi terbatasnya pengontrolan dengan timer, penulis menyarankan untuk waktu pengontrolan dapat dirubah sesuai kebutuhan pengguna.

3. Penggunan lampu untuk rangkaian diming, penulis menyarankan untuk menggunakan lampu pijar saja. Apabila menggunakan jenis lampu yang lain, rangkaian diming dapat merusak filamen lampu.

\section{DAFTAR PUSTAKA}

Budihart, W., dan Gamyel, R., (2007), 12 Proyek Mikrokontroler Untuk Pemula, Penerbit Elex Media Kompuutindo, Jakarta.

Fatoni, A., dan Bayu, D., (2014), Perancangan Prototype Sistem Kendali Lampu Menggunakan Handphone Android Berbasis Arduino, Jurnal Prosisko, 1 : 2406-7733

Henny dan Sutardi., (2016), Sistem Pengendali Lampu Listrik Berbasis Mikrokontroler Atmega328 Pada Smartphone Android, Jurnal Sistem Informasi dan tehnik Komputer Catur Sakti, 1: 2502-5899

Isnawaty., Mayangsari, A S., Rachman, A., (2016), Sistem Kendali Penerangan Ruangan Untuk Mengurangi Konsumsi Energi Listrik Dengan Pemanfaatan Android Dan Bluetooth, Dinamika Jurnal Ilmiah Teknik Mesin, 7: 2085-8817

Kadir, A., (2012) Panduan Praktis Mempelajari Aplikasi Mikrokontroler dan Pemogramannya Menggunakan Arduino, Penerbit C.V Andi OFFSET, Yogyakarta.

RM Kholil, U dan Prapanca, A., (2018), Mengontrol Lampu Rumah Berbasis Web Dengan Memanfaatkan Sistem General Purpose Input/Output (Gpio) Pada Router Openwrt,Jurnal Manajemen Informatika, 08: 37-44
Yan, M., dan Shi , H., (2013), Smart Living Using Bluetooth based Android Smartphone, International Journal of Wireless \& Mobile Networks, 5 